\title{
The Management of Crown Fracture of Immature Teeth by MTA and Calcium Hydroxide: Case Reports
}

\author{
Buthina Alhaddad*, Ildikó Tarján and Noémi Rózsa
}

Department of Paedodontics and Orthodontics, Faculty of Dentistry, Semmelweis University, Budapest, Hungary

\begin{abstract}
This article describes the treatment of immature maxillary central incisors associated with complicated crown fracture with periapical lesion in two clinical cases. For the first, the root-canal was filled with $\mathrm{Ca}(\mathrm{OH})_{2}$ (calcium hydroxide) as an interim dressing followed by mineral trioxide aggregate (MTA). In the second case, an incomplete obturation of left maxillary central incisor, the root canal was filled with calcium hydroxide.

The advantages and disadvantages of $\mathrm{Ca}(\mathrm{OH})_{2}$ and MTA are discussed. Both materials are effective in the treatment of immature teeth. The advantages of MTA demonstrate its potential for replacing calcium hydroxide in endodontic procedures in the near future.
\end{abstract}

Keywords: Calcium hydroxide; Mineral trioxide aggregate; Root canal treatment; Immature teeth

\section{Introduction}

Traumatic injuries to teeth with or without pulpal involvement occur in children and adolescents [1]. The majority of these injuries occur before root formation is complete, causing in some cases pulp inflammation and necrosis, with possible impact on the quality of life of affected individuals [2,3]. Anterior crown fractures are favoured by the protruded position of maxillary incisors and their eruptive pattern. The most susceptible age to dental trauma is between 6 to 12 years [4]. Complicated crown fractures represent $18-20 \%$ of all traumatic injuries to permanent teeth [5]. The treatment options vary due to tooth maturity, the time lapse between the accident and the treatment, the severity of pulp exposure, the presence or absence of haemorrhage, the size of the remaining crown, periodontal status and occlusal relations [6,7].

Root formation is classified in seven stages by Moorrees et al. [8]. Vital amputation (pulpotomy) is the treatment of choice for traumatized immature teeth with pulp exposure [9,10]. It allows further root development, with apical closure and strengthening of the root structure [9]. If the pulp vitality of a traumatized immature tooth is lost, the treatment will be a challenge, especially for pulp necrosis in teeth with inadequate radicular development due to the fact that an open apex in permanent tooth takes approximately 3 years to close after tooth eruption $[2,9,11-13]$. In the case of pulp necrosis, pulpectomy and root canal therapy should be preferred [12]. If the apex is not completely formed, the standard treatment option for traumatized immature permanent teeth with necrotic pulp is apexification. The aim is to induce a hard calcified barrier at the apical end of the root to achieve the definitive root canal filling [14]. The traditional, long-term radicular closure procedure applies calcium hydroxide, $\mathrm{Ca}(\mathrm{OH})_{2}[15]$. This technique was the mainstay for the management of immature apices for over half a decade [16]. $\mathrm{Ca}(\mathrm{OH})_{2}$ is the most widely accepted material, due to its biological and antimicrobial properties, such as reparative dentin to bridge a pulp exposure, induction of hard tissue formation and ability to stimulate the formation of new bone, healing of large periradicular lesions and inhibition of root resorption [1719]. $\mathrm{Ca}(\mathrm{OH})_{2}$ dressing helps to eliminate the microorganisms and inactivates toxic products $[20,21]$. The lethal effect of calcium hydroxide on bacterial cells is probably due to protein denaturation and damage to DNA and cytoplasmic membranes [22]. $\mathrm{Ca}(\mathrm{OH})_{2}$ has been also used as a temporary filling material for non-vital tooth with immature apex [13]. The average time for apical barrier formation ranges from 5 months to 20 months [23].

In recent times, interest has centred on the use of mineral trioxide aggregate (MTA), due to its wide array of application in the treatment of complications following dental trauma. These conditions include teeth with exposed pulp, root fracture and pulp necrosis located in the coronal part of the pulp [24-26]. It is the material of choice as an apical plug during the short-term (one-visit) apexification techniques, and adjuvant, placed as a cervical plug in the regenerative endodontic treatment (RET) based on revascularisations techniques [15]. Hydration of MTA powder results in a colloidal gel composed of calcium oxide crystals in an amorphous structure [27]. The use of MTA in endodontics is due to the beneficial properties of this material like ease of manipulation and placement [28]. It neither gets resorbed, nor weakens the root canal dentinal structures [29]. It is insensitive to moisture and blood [16,30]. It shows antimicrobial properties, biocompatibility, low shrinkage and the capacity to induce cementum and periodontal ligament (PDL) formation [14,24,31,32]. During setting time, the $\mathrm{pH}$ is between 10.2 and 12.5, favouring hard tissue induction and creating a bacteria-tight seal [14,20,33,34].

The following two clinical case reports describe the successful treatment of non-vital immature upper right central incisor with periapical infection suffered from complicated crown fracture and the management of immature upper central incisors with incomplete root canal obturation.

\section{Case Report-1}

An 8 year old boy reported to the Pedodontic and Orthodontic Department of the Dental Faculty of Semmelweis University, Budapest for evaluation and treatment of a right maxillary central incisor. $\mathrm{He}$

*Corresponding author: Buthina Alhaddad, Department of Paedodontics and Orthodontics, Faculty of Dentistry, Semmelweis University, H-1088 Budapest, Szentkirályi u. 47, Budapest, Hungary, Tel: +36708857208; E-mail: dr.alhaddad.buthina@gmail.com

Received November 18, 2015; Accepted December 09, 2015; Published December 16, 2015

Citation: Alhaddad B, Tarján I, Rózsa N (2015) The Management of Crown Fracture of Immature Teeth by MTA and Calcium Hydroxide: Case Reports. Dentistry 5: 347 doi:10.4172/2161-1122.1000347

Copyright: (c 2015 Alhaddad B, et al. This is an open-access article distributed under the terms of the Creative Commons Attribution License, which permits unrestricted use, distribution, and reproduction in any medium, provided the original author and source are credited. 
had suffered traumatic injury during a mobile accident with loss of the coronal fragment of teeth 1.1 and 2.1. The clinical examination revealed complicated crown fracture of the right upper central incisor. The tooth failed to respond to thermal or electric pulp testing. Periapical radiographs demonstrated incompletely formed root apex and periapical radiolucency. The root developmental stage 2 to 3 was established according to Moorrees et al. (Figure 1) [8]. Because of difficulties in the disinfection and drying of the root canal, a modified short-term apexification technique was chosen as treatment option.

A conventional access opening was made under absolute isolation conditions. The root length was estimated using periapical radiograph. Root canal instrumentation was performed, and the working length was established at $1 \mathrm{~mm}$ short of the radiographic apex. Copious irrigation with $0.5 \%$ sodium hypochlorite $(\mathrm{NaOCl})$ was done throughout the cleaning and shaping procedures. The root canal was dried with absorbent paper points, and filled with calcium hydroxide. $\mathrm{Ca}(\mathrm{OH})_{2}$ was changed at one week intervals over two months, and the access cavity was restored with a glass ionomer temporary restoration.

At the 2 months check-up, the tooth was asymptomatic and showed no tenderness to percussion and palpation. The temporary restoration was removed and again the canal was irrigated with $0.5 \% \mathrm{NaOCl}$. The canal was enlarged up to size of root canal instrument ISO number 80. MTA was mixed according to the manufacturer's instruction and was applied with hand plugger. Control radiograph showed a thickness of MTA about $4 \mathrm{~mm}$. Hardness of apical plug was checked after 1 week and the canal was obturated with heated gutta-percha and a sealer using lateral condensation technique (Figure 2). For the final crown restoration of both fractured upper central incisors light-curing composite material was used.

After one year, radiographic examination of tooth 1.1 showed apical closure and decrease of the radiolucent area was evident (Figure 3 ). The two year check-up revealed complete healing of the apical structures (Figure 4).

\section{Case Report-2}

A 7 year old boy was referred to the department with traumatic fracture in the left maxillary central incisor due to a sports accident at school. The clinical examination revealed a complicated crown fracture (Figure 5) with tooth mobility within normal limits. Radiographic examination detected immature teeth with open apices and a large radiolucent area. The root developmental stage 3 to 4 was established according to Moorrees et al. [8]. The tooth was accessed; root canals

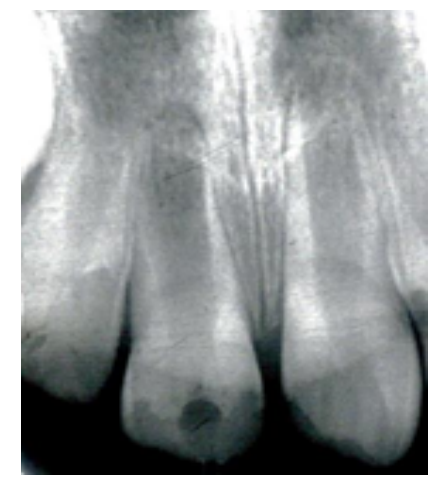

Figure 1: Incompletely formed root length and wide open apex for teeth 1.1, 1.2 and 2.2; complicated crown fracture with pulpal involvement of tooth 1.1; crown fracture without pulpal involvement for tooth 2.1.

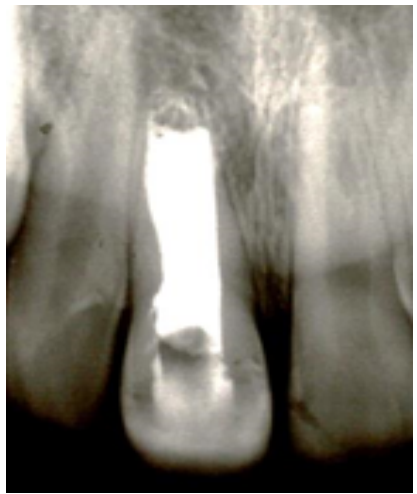

Figure 2: The MTA apical plug and gutta-percha filling of tooth 1.1.

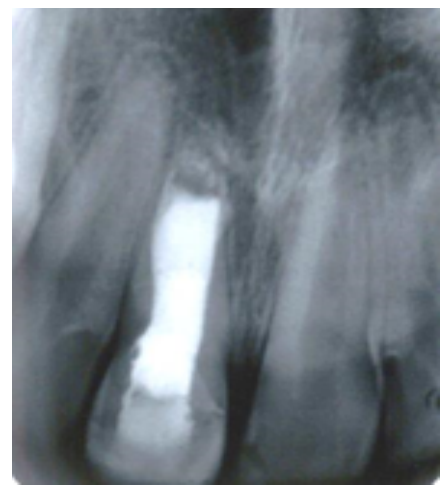

Figure 3: Check-up after one year.

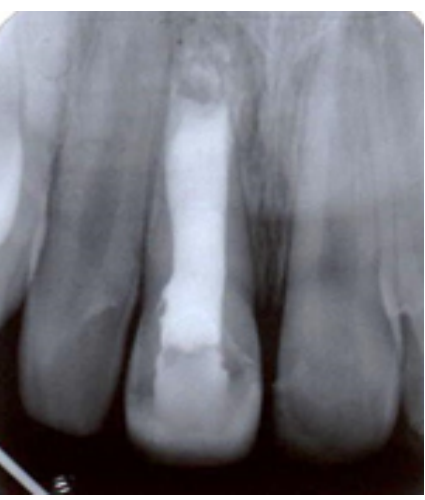

Figure 4: Check-up after two years.

were cleaned and instrumented (Figure 6). Irrigation with $0.5 \% \mathrm{NaOCl}$ was applied. Disinfection and mechanical root canal treatment was extremely difficult and performed with great care because of the thin dentinal root walls and open apex. The large periapical lesion made appropriate drying also difficult and time-consuming, therefore the long-term apexification using $\mathrm{Ca}(\mathrm{OH})_{2}$ was chosen. The tooth was restored with temporary glass ionomer cement. $\mathrm{Ca}(\mathrm{OH})_{2}$ dressing was changed every three months. Periapical radiograph were taken periodically. After 12 months, X-ray examination showed complete formation of the root apices in left maxillary central incisor. Permanent root canal obturation with half heated gutta-percha was performed, 


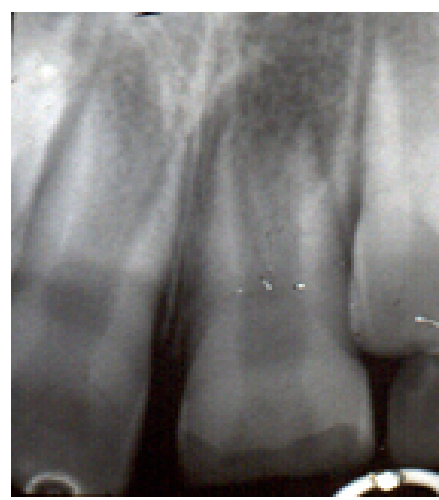

Figure 5: Left upper maxillary central incisor before treatment showing large radiolucency in the periapical area.

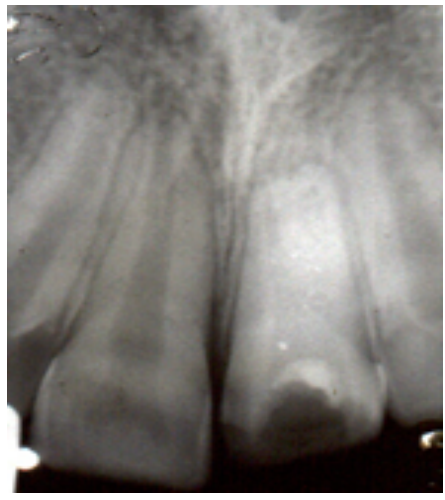

Figure 6: Calcium hydroxide dressing of the root for tooth 2.1 .

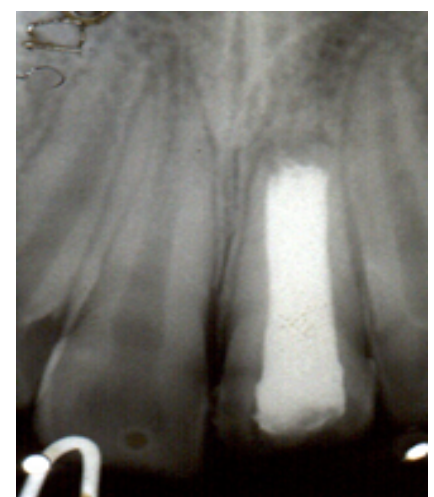

Figure 7: Permanent gutta-percha root canal obturation; 1 year radiographic check-up.

followed by additional points, dipped in resin-chloroform using lateral condensation. On the control radiographic examination made after one year periapical healing was evident (Figure 7).

\section{Discussion}

Despite the higher success rate of apical barrier formation using $\mathrm{Ca}(\mathrm{OH})_{2}$, it still has its inherent clinical problems, like the possibility of cervical root fracture of the weakened teeth because of the desiccating properties of high $\mathrm{pH} \mathrm{Ca}(\mathrm{OH})_{2}$, failure to control infection, multiple appointments, which complicated the treatment, the nature of barrier which might be porous or sometimes contains soft tissues $[13,14,20,29,31,35,36]$. The presence of $\mathrm{Ca}(\mathrm{OH})_{2}$ paste in the root for more than 30 days, and the long-term treatment procedures raise the tooth susceptibility to fracture $[15,35,36]$. Disadvantages of $\mathrm{Ca}(\mathrm{OH})$ can be the variability of treatment time, unpredictability of apical closure, high rate of cervical root fracture, difficulties with patient follow-up and delayed treatment [37].

The use of materials potentially inducing mineralisation such as MTA can be used to avoid these inconveniences [14]. Portland cement bismuth oxide MTA is the first material that consistently allows for the overgrowth of cementum and bone formation, furthermore it facilitates the regeneration of the periodontal ligament $[30,38]$ and is achieving a hermetic seal against bacteria $[24,31,38]$. These properties resulting in the combination of an effective bacterial seal and formation of new cementum and PDL makes techniques using MTA a biologically preferable method and MTA a gold standard root filling material for immature teeth with open apex [24,38]. However, MTA has certain drawbacks such as difficulty in handling and very slow setting reaction, which might contribute to leakage, surface disintegration, loss of marginal adaptation and continuity of the material [38].

Many studies compared the effectiveness of $\mathrm{Ca}(\mathrm{OH})_{2}$ versus MTA, and concluded, that MTA equals $\mathrm{Ca}(\mathrm{OH})_{2}$ cases with open apex. Further, it has proven to be effective in performing the same procedure in a considerably shorter period of time with more predictable results [28]. By using MTA as a physical barrier apically, root canal filling can be placed immediately without waiting for biological response [37]. MTA was effective in severe crown fracture too [20]. In cases where the initial treatment of the injured tooth included long-term apexification with $\mathrm{Ca}(\mathrm{OH})_{2}$ showing no apical stop 3 years later, by replacing it with MTA at the 12 months follow up the tooth was asymptomatic and showed repair of the radiolucent apical lesion [39]. The treatment with $\mathrm{Ca}(\mathrm{OH})_{2}$ is time consuming, ranging from 3 to 21 months, dependent on the diameter of open apex, the rate of tooth displacement and the tooth repositioning method after luxation injury [35]. Lemon advocated the use of a matrix when the perforation diameter is larger than $1 \mathrm{~mm}$ to avoid extrusion of the sealing material [28].

In the second case presented, at the moment of injury the root canal was in an early stage of development. Moorrees et al. reported that in early root developmental stages (between 2 and 4), $\mathrm{Ca}(\mathrm{OH})_{2}$ helps not only regeneration of surrounding bone tissue and periodontium, but also subsequent closing of wide apical opening [8]. This was taken into consideration at treatment choice for Case 2 . The required treatment time was 12 months. A complete formation of the root apices was achieved with complete periapical healing. $\mathrm{Ca}(\mathrm{OH})_{2}$ was applied as temporary filling material also in the apical regions, producing better results than placed beyond the coronal half [40]. In the first case, an apical plug of MTA was used for short-time apexification in a combined treatment method. $\mathrm{Ca}(\mathrm{OH})_{2}$, was applied as root canal medicament dressing for two months. According to Moorrees et al. when the root formation is in stages between 3 and 4 , the use of $\mathrm{Ca}(\mathrm{OH})_{2}$ for one or two months before the application of MTA helps the apex closure, the drying process, keeping the root canal free from microorganisms and most of endodontic pathogens $[8,21,25,29]$. This results in avoiding infections induced by acidic environment which could adversely affect the setting of MTA [25]. During root canal debridement, the canals were irrigated with $\mathrm{NaOCl}$ in both cases. $\mathrm{NaOCl}$ was diluted to $0.5 \%$ to limit the potential for apical tissue damage [25]. In both cases $\mathrm{Ca}(\mathrm{OH})_{2}$ dressings were placed without triple antibiotic paste to avoid teeth 
discoloration due to minocycline [15,41]. For Case 1 after $\mathrm{Ca}(\mathrm{OH})$ medication, a plug of $4 \mathrm{~mm}$ of MTA was introduced to the apical parts of the canal with a fitted gutta-percha cone under radiographic evaluation. MTA has been considered an excellent root-end filling material as it provides good sealing ability and is biocompatible to periapical tissues [12]. The apex closure finalized within one year, and two-year follow-up showed good periapical repair.

\section{Conclusion}

The presented cases and their treatment showed that both MTA and $\mathrm{Ca}(\mathrm{OH})_{2}$ apexification techniques are effective in achieving an apex closure with barrier formation of immature teeth in young patients. For MTA, the duration for periapical tissues healing around the apex was less than the required time when using $\mathrm{Ca}(\mathrm{OH})_{2}$. Although $\mathrm{Ca}(\mathrm{OH})_{2}$ is effective in apexification process, but due to the long healing process and such the possibility of crown fracture, the use of MTA seems to be a better option in endodontic treatment of immature teeth.

The combined use of calcium hydroxide as adjuvant medication before the application of MTA in immature teeth helps drying the canal and keeping it free from infection and microorganisms. It also promotes the apical closure process. Apexogenesis and apexification of traumatized young permanent teeth requires a complex therapy and even for necrotized teeth the revascularization procedures are being more and more emphasized.

\section{References}

1. Fidel SR, Fidel-Junior RA, Sassone LM, Murad CF, Fidel RA (2011) Clinica management of a complicated crown-root fracture: a case report. Braz Dent J 22: 258-262.

2. Dixit S, Dixit A, Kumar P, Arora S (2014) Root End Generation: An Unsung Characteristic Property of MTA-A Case Report. J Clin Diagn Res 8: 291-293.

3. Dame-Teixeira N, Alves LS, Ardenghi TM, Susin C, Maltz M (2013) Traumatic dental injury with treatment needs negatively affects the quality of life of Brazilian schoolchildren. Int J Paediatr Dent 23: 266-273.

4. Vijayaprabha K, Marwah N, Dutta S (2012) A biological approach to crown fracture: Fracture reattachment: A report of two cases. Contemp Clin Dent 3: S194-S198.

5. Emine ST, Tuba UA (2011) White mineral trioxide aggregate pulpotomies: Two case reports with long-term follow-up. Contemp Clin Dent 2: 381-384.

6. Asgary S, Fazlyab M (2014) Management of Complicated Crown Fracture with Miniature Pulpotomy: A case report. Iran Endod J 9: 233-234.

7. Vishwanath B, Faizudin U, Jayadev M, Shravani S (2013) Reattachment of coronal tooth fragment: regaining back to normal. Case Rep Dent 2013: 286186.

8. Moorrees CF, Fanning EA, Hunt EE Jr. (1963) Age Variation of Formation Stages for Ten Permanent Teeth. J Dent Res 42: 1490-1502.

9. Forghani M, Parisay I, Maghsoudlou A (2013) Apexogenesis and revascularization treatment procedures for two traumatized immature permanent maxillary incisors: a case report. Restor Dent Endod 38: 178-181.

10. Witherspoon DE (2008) Vital pulp therapy with new materials: new directions and treatment perspectives-permanent teeth. J Endod 34: S25-S28.

11. Aggarwal V, Miglani S, Singla M (2012) Conventional apexification and revascularization induced maturogenesis of two non-vital, immature teeth in same patient: 24 months follow up of a case. J Conserv Dent 15: 68-72.

12. Fidel RA, Carvalho RG, Varela CH, Letra A, Fidel SR (2006) Complicated crown fracture: a case report. Braz Dent J 17: 83-86.

13. Vellore KG (2010) Calcium hydroxide induced apical barrier in fractured nonvital immature permanent incisors. J Indian Soc Pedod Prev Dent 28: 110-112.

14. Beslot-Neveu A, Bonte E, Baune B, Serreau R, Aissat F, et al. (2011) Mineral trioxyde aggregate versus calcium hydroxide in apexification of non vital immature teeth: study protocol for a randomized controlled trial. Trials 12: 174
15. Fuks AB, Heling I, Nuni E (2013) Pulp Therapy for the Young Permanent Dentition. In: Pediatric Dentistry: Infancy through Adolescence. ( $5^{\text {th }}$ edn), Mosby, St. Louis.

16. Nuvvula S, Melkote TH, Mohapatra A, Nirmala S (2010) Management of immature teeth with apical infections using mineral trioxide aggregate. Contemp Clin Dent 1: 51-53.

17. Rosenberg B, Murray PE, Namerow K (2007) The effect of calcium hydroxide root filling on dentin fracture strength. Dent Traumatol 23: 26-29.

18. Asgary S, Akbari Kamrani F, Taheri S (2007) Evaluation of antimicrobial effect of MTA, calcium hydroxide, and CEM cement. Iran Endod J 2: 105-109.

19. Strom TA, Arora A, Osborn B, Karim N, Komabayashi T, et al. (2012) Endodontic release system for apexification with calcium hydroxide microspheres. J Dent Res 91: 1055-1059.

20. Andreasen JO, Andreasen FM, Andersson L (2007) Textbook and Color Atlas of Traumatic Injuries to the Teeth. ( $4^{\text {th }}$ edn), Blackwell Munksgaard, Oxford.

21. Hariharan VS, Nandlal B, Srilatha KT (2010) Management of recurrent fracture of central incisor with internal resorption using light transmitting (luminex) post. $J$ Indian Soc Pedod Prev Dent 28: 288-292.

22. Mohammadi Z, Dummer PM (2011) Properties and applications of calcium hydroxide in endodontics and dental traumatology. Int Endod J 44: 697-730.

23. Sheehy EC, Roberts GJ (1997) Use of calcium hydroxide for apical barrier formation and healing in non-vital immature permanent teeth: a review. Br Dent J 183: 241-246.

24. Bakland LK, Andreasen JO (2012) Will mineral trioxide aggregate replace calcium hydroxide in treating pulpal and periodontal healing complications subsequent to dental trauma? A review. Dent Traumatol 28: 25-32.

25. Fayazi S, Bayat-Movahed S, White SN (2013) Rapid endodontic management of type II dens invaginatus using an MTA plug: a case report. Spec Care Dentist 33: 96-100.

26. Gawthaman M, Vinodh S, Mathian VM, Vijayaraghavan R, Karunakaran R (2013) Apexification with calcium hydroxide and mineral trioxide aggregate: Report of two cases. J Pharm Bioallied Sci 5: S131-S134.

27. Gudkina J, Mindere A, Locane G, Brinkmane A (2012) Review of the success of pulp exposure treatment of cariously and traumatically exposed pulps in immature permanent incisors and molars. Stomatologija 14: 71-80.

28. Khatavkar RA, Hegde VS (2010) Use of a matrix for apexification procedure with mineral trioxide aggregate. J Conserv Dent 13: 54-57.

29. Chhabra N, Singbal KP, Kamat S (2010) Successful apexification with resolution of the periapical lesion using mineral trioxide aggregate and demineralized freeze-dried bone allograft. J Conserv Dent 13: 106-109.

30. Tanalp J, Karapinar-Kazandag M, Ersev H, Bayirli G (2012) The status of mineral trioxide aggregate in endodontics education in dental schools in Turkey. J Dent Educ 76: 752-758.

31. Dhaimy S, Lahlou K, Karami M, Elmerini H, Elouazzani A (2013) Periapical regeneration. About one case of necrotic immature tooth treated with mineral trioxide aggregate (MTA). Odontostomatol Trop 36: 39-44.

32. Milani AS, Rahimi S, Borna Z, Jafarabadi MA, Bahari M, et al. (2012) Fracture resistance of immature teeth filled with mineral trioxide aggregate or calciumenriched mixture cement: An ex vivo study. Dent Res J (Isfahan) 9: 299-304.

33. Economides N, Pantelidou O, Kokkas A, Tziafas D (2003) Short-term periradicular tissue response to mineral trioxide aggregate (MTA) as root-end filling material. Int Endod J 36: 44-48.

34. Gomes-Filho JE, Watanabe S, Cintra LT, Nery MJ, Dezan-Junior E, et al (2013) Effect of MTA-based sealer on the healing of periapical lesions. J App Oral Sci 21: 235-242.

35. Gunes B, Aydinbelge HA (2012) Mineral trioxide aggregate apical plug method for the treatment of nonvital immature permanent maxillary incisors: Three case reports. J Conserv Dent 15: 73-76.

36. Tabrizizade M, Asadi Y, Sooratgar A, Moradi S, Sooratgar H, et al. (2014) Sealing ability of mineral trioxide aggregate and calcium-enriched mixture cement as apical barriers with different obturation techniques. Iran Endod J 9: 261-265.

37. Linsuwanont $P$ (2003) MTA apexification combined with conventional roo canal retreatment. Aust Endod J 29: 45-49. 
Citation: Alhaddad B, Tarján I, Rózsa N (2015) The Management of Crown Fracture of Immature Teeth by MTA and Calcium Hydroxide: Case Reports. Dentistry 5: 347. doi:10.4172/2161-1122.1000347

38. Girish CS, Ponnappa K, Girish T, Ponappa M (2013) Sealing ability of minera trioxide aggregate, calcium phosphate and polymethylmethacrylate bone cements on root ends prepared using an Erbium: Yttriumaluminium garnet laser and ultrasonics evaluated by confocal laser scanning microscopy. J Conserv Dent 16: 304-308.

39. Maroto M, Barberia E, Planells P, Vera V (2003) Treatment of a non-vital immature incisor with mineral trioxide aggregate (MTA). Dent Traumatol 19: 165-169.
40. Bose R, Nummikoski P, Hargreaves K (2009) A retrospective evaluation of radiographic outcomes in immature teeth with necrotic root canal systems treated with regenerative endodontic procedures. J Endod 35: 1343-1349.

41. Kim JH, Kim Y, Shin SJ, Park JW, Jung IY (2010) Tooth discoloration of immature permanent incisor associated with triple antibiotic therapy: a case report. J Endod 36: 1086-1091. 